\title{
Effects of the 2,4-D herbicide on gills epithelia and liver of the fish Poecilia vivipara ${ }^{1}$
}

\author{
Ana F. Vigário ${ }^{2 *}$ and Simone M.T. Sabóia-Morais ${ }^{3}$
}

\begin{abstract}
Vigário A.F. \& Sabóia-Morais S.M.T. 2014. Effects of the 2,4-D herbicide on gills epithelia and liver of the fish Poecilia vivipara. Pesquisa Veterinária Brasileira 34(6):523-528. Departamento de Ciências Biológicas, Universidade Federal de Goiás, Campus Catalão, Avenida Lamartine P. Avelar 1120, Setor Universitário, Catalão, GO 75704-020, Brazil. E-mail: afvbioufg@gmail.com

The 2,4-dichlorophenoxyacetic acid, usually named 2,4-D is one of the most widely used herbicides in the world. Acute toxicity of 2,4-D herbicide was investigated through its effects on guppies (Poecilia vivipara Bloch et Schneider 1801). Fish were exposed to the herbicide at concentrations of 10, 20 and $40 \mu \mathrm{l}$ per liter of water for 24 hours to determine its effects on gills and liver epithelia. The estimated LC50 was 34.64 $\mu \mathrm{l}$ of 2,4-D per liter of water. Histochemical analyses and Feulgen's reaction were conducted to detect glycoconjugates and DNA, respectively, in gills and liver epithelia. Histochemistry revealed qualitative variations of glycoconjugates present on mucous cells and granules. The four types of mucous cells contained neutral granules, acids, or both. Increasing amounts of syalomucins were observed from the control group to the group exposed to the highest concentration of 2,4-D, suggesting increased mucous viscosity and the formation of plaques that could inhibit gas exchange and osmoregulation. Lamellar fusion observed in the group exposed to $40 \mu \mathrm{l}$ of 2,4-D suggests a defense mechanism. Hepatocytes showed vacuolization in the 10 and $20 \mu \mathrm{l} / \mathrm{L}$ groups. The $40 \mu \mathrm{l} / \mathrm{L}$ group showed normal hepatocytes as well as changed ones, many Ito cells, micronuclei, and nuclear swelling. These effects may be associated with toxicity or adaptative processes to cellular stress. The data from this study indicates the importance of assessing similar risks to aquatic species and suggests that Poecilia vivipara is an adequate biological model for analysis of environmental contamination.
\end{abstract}

INDEX TERMS: 2,4-D herbicide, gill, fish, Poecilia vivipara, histopathology, glycoconjugates, xenobiotics, genotoxic potential.

RESUMO.- [Efeitos do herbicida 2,4-D no epitélio das brânquias e no fígado do peixe Poecilia vivípara.] A toxicidade aguda do herbicida 2,4-D foi investigada através dos efeitos no peixe Poecilia vivípara (Bloch et Schneider, 1801). Grupos de peixes foram expostos ao herbicida nas concentrações de 10, 20 e $40 \mu \mathrm{l}$ por litro de água, durante 24 horas. As brânquias e o fígado foram estudados. A concentração letal média (CL50) do herbicida para a espécie em questão foi de $34,64 \mu \mathrm{l} / \mathrm{l}$. Foram realizadas colorações

\footnotetext{
${ }^{1}$ Received on November 20, 2013.

Accepted for publication on May 27, 2014.

${ }^{2}$ Departamento de Ciências Biológicas, Universidade Federal de Goiás, Campus Catalão, Av. Lamartine P. Avelar, 1120, Setor Universitário, Catalão, GO 75704-020, Brazil.. *Corresponding author: afvbioufg@gmail.com

${ }^{3}$ Laboratório de Comportamento Celular, Departamento de Morfologia, Instituto de Ciências Biológicas (ICB), Universidade Federal de Goiás (UFG), Campus II, ICB IV, Cx. Postal 131, Goiânia, GO 74001-970, Brazil.
}

histoquímicas e coloração de Feulgen para identificar glicoconjugados e DNA, respectivamente, nos tecidos acima citados. Os métodos histoquímicos revelaram os tipos de glicoconjugados presentes nas células mucosas e nos grânulos. Os quatro tipos de células mucosas apresentaram glicoconjugados neutros, ácidos, ou ambos em um mesmo tipo celular. Observou-se a presença crescente de sialomucinas do grupo controle até o grupo exposto a maior concentração de 2,4-D, sugerindo aumento da viscosidade do muco e, consequentemente, formação de placas que impedem as trocas gasosas e a osmorregulação. A fusão lamelar observada no grupo exposto a $40 \mu \mathrm{l}$ de $2,4-\mathrm{D}$ sugere ser um mecanismo de defesa. Os hepatócitos apresentaram processo de vacuolização nos grupos 10 e $20 \mu \mathrm{l} / \mathrm{l}$. No grupo de $40 \mu \mathrm{l} / \mathrm{l}$, observou-se a presença de células de Ito, micronúcleos e hepatócitos normais e outros com edema nuclear. Este estudo indica a importância da avaliação de riscos se- 
melhantes a espécies aquáticas e sugere a espécie Poecilia vivipara como modelo biológico adequado para análises de contaminação ambiental.

TERMOS DE INDEXAÇÃO: Herbicida 2,4-D, peixe, Poecilia vivípa$r a$, histopatologia, glicoconjugados, xenobióticos, potencial genotóxico.

\section{INTRODUCTION}

Chemicals play an important role in modern farm practices (Farah et al. 2004). Agricultural pesticides used against pests, undesirable herbs and agricultural diseases have been found to have adverse effects on the environment (Sarikaya \& Yilmaz 2003). Environmental toxicology studies have confirmed that pesticides affect non-target species in the environment because these substances are not fully selective (Rao 2006). Pesticides are applied to crops in large amounts, only a small portion of which reaches the target. The other portions can have various effects on wildlife, insects, soil microorganisms and aquatic organisms, including reduced biodiversity, reproductive and behavioral alterations, increased disease susceptibility, and accumulation of toxic substances that can reach humans through the food chain (Ozmen et al. 2008). Alterations of the chemical composition of natural aquatic environments can affect all fauna present, especially fish (Oruc et al. 2004).

According to Spadotto et al. (1998), Brazil is one of the world's largest consumers of pesticides; use of pesticides in Brazil has surpassed agricultural growth over the past 30 years. Many organophosphorous and organochlorinated compounds used in Brazil have been forbidden or restricted in more than 50 countries due to their high toxicity and long persistence in the environment (Rodrigues \& Almeida 1998). Pesticide toxicity is highly dependent on concentration, frequency, intensity of exposure, and target organism susceptibility, which, in turn, is influenced by age, sex, health state and genetic variations (Fent 2003, 2004). 2,4-dichlorophenoxyacetic acid (2,4-D) is a common herbicide that was introduced into commerce in 1946 and rapidly came to be used worldwide. It is employed for post-emergence foliar spray and is also used for weed control of wheat, rice, maize and aquatic weeds (Farah et al. 2004). The Poecilia vivipara (Bloch et Schneider 1801) guppy is a teleostean and euryhaline fish, distributed in the American continent. This small-sized fish is ovoviviparous with internal fertilization and presents sexual dimorphism (Sabóia-Morais et al. 1996). It has moderate sensitivity to environmental alterations.

Various methodologies are used to detect effects of toxic substances on organisms, including histopathology, histochemistry, and the use of biochemical markers. Histopathological alterations generate distinct morphological patterns that can be used to identify drug responses (Henares et al. 2008). Histochemical reactions and biochemical studies can be used to analyze the behavior of secretory cells when exposed to environmental factors. The purpose of this work was to identify the lethal concentration (LC50) of 2,4-D herbicide in guppies, to identify morphological alterations of the branchial epithelium and liver of this fish, and to analyze possible alterations of animal and cellular behavior.

\section{MATERIALS AND METHODS}

The herbicide 2,4-dichlorophenoxyacetic acid (2,4-D) (U46 ${ }^{\circledR} \mathrm{D}$ -FLUID 2,4-D - Dow AgroSciences Industrial Ltda) was used in a concentrated aqueous solution containing the dimethylamine salt of 2,4-D acid at a concentration of $868 \mathrm{~g} / \mathrm{L}$; the 2,4-D acid equivalent was $720 \mathrm{~g} / \mathrm{L}$.

Guppies collected from non-polluted lakes and small rivers (latitude south $16^{\circ} 43^{\prime}$; longitude west $49^{\circ} 20^{\prime}$ ) are routinely reared in our laboratory. One hundred eighty-four specimens were randomly chosen and kept in three aquariums of 40 liter capacity supplied with fresh tap water. Water temperature, oxygenation and $\mathrm{pH}$ in the aquaria were periodically checked throughout the experiment. A $12 \mathrm{~h}$ light/12h dark cycle was maintained, and the fish were fed with commercial fish food (Alcon Basic Ltda, Santa Catarina, Brazil). All procedures described above were assessed, accepted and approved by the Ethics Committee on Animal Experiments of the Hospital das Clínicas, Federal University of Goiás (project docketed under No. 126).

The lethal concentration (LC50) was tested by exposing 10 fish per group to 10,20 and $40 \mu$ l of 2,4-D herbicide per liter of water for 48 hours. For experimental procedures, acclimated fish were randomly chosen and separated into small tanks (2 liter volume) supplied with fresh tap water. The acute toxicity of 2,4-D on Poecilia vivipara was determined using the Spearman-Karber program made available by the Environmental Protection Agency of the United States of America (USA EPA). Individual groups of thirty-six fish were exposed for 24 hours to 10,20 and $40 \mu \mathrm{l}$ of toxic 2,4-D herbicide per liter of water. The control group was kept in experimental water without 2,4-D with all of other conditions kept constant. Each group of guppies was monitored in order to identify macroscopic signs of morphopathology and mortality. Experiments were carried out using static acute experimental methodology. At the end of the acute tests, water samples from all tanks were collected and taken to the Water Laboratory of Saneamento de Goiás (Saneago), where tests were carried out according to AWWA (1964) protocols.

After acute testing ( 24 hours), all fish manipulations were performed after anesthesia with benzocaine. Tissues were fixed in Karnovsky solution and embedded in Paraplast (Oxford, St Louis, MO, USA). Sections of $4 \mu \mathrm{m}$ were cut and stained with hematoxylin and eosin (HE) and toluidine blue for histology. Periodic acid Schiff (PAS), PAS+amilasis, and PAS+acetylation histochemical reactions were used to detect glycoconjugates, and PAS+reversible acetylation was performed to identify neutral mucins. Differentiation of acid mucins (sialomucins and sulphomucins) was accomplished using Alcian blue (AB) pH 2.5 for caboxylated and sulphated mucins, $\mathrm{AB} \mathrm{pH} 0.5$ for sulphated mucins, and variations of $\mathrm{AB} \mathrm{pH} 2.5$ such as $\mathrm{AB}+$ methylation, $\mathrm{AB}+$ reversible methylation, and $\mathrm{PAS}+\mathrm{AB}$. Additionally, Feulgen's reaction was used for DNA detection. All sections were analyzed and photographed using an Olympus CH30 microscope.

\section{RESULTS}

\section{Lethal concentration (LC50)}

The estimated LC50 was $34.64 \mu \mathrm{l}$ of 2,4-D per liter of water. This value was determined using the Spearman-Karber program (USA EPA) after 48 hours of exposure. At the end of the test, fish were observed macroscopically in order to detect external physiological and morphological anomalies. Three fish in the $10 \mu \mathrm{l} / \mathrm{L}$ group presented signs of vasodila- 
tation followed by hemorrhaging in the proximal region of their caudal fin. All fish exposed to 20 or $40 \mu \mathrm{l} / \mathrm{L}$ of herbicide showed signs of high gill vascularization, and 2 fish had characteristics similar to those of the $10 \mu \mathrm{l} / \mathrm{L}$ group. Gall bladders in all experimental groups showed increased gall volume and were emerald green in color.

Acute toxicity - histological and histochemical analyses

The most common gill alterations included epithelial hyperplasia, lamellar fusion and changes in glycoconjugate granules of mucous cells. In the control group, gills presented normal histoarchitecture. Mucous cells of the filament and rake epithelia had glycoconjugate granules with 1,2-vic-glycol groups as well as neutral, acidic, carboxylated and acidic sulphated groups, with the latter in less quantity. The presence of syalomucins was also detected.

At $10 \mu \mathrm{l} / \mathrm{L}$, branchial lamellae presented stiffness and a loss of their natural anatomic curvature. Interlamellar and mucous cells had glycoconjugates similar to the control group. In the $20 \mu \mathrm{l} / \mathrm{l}$ group, the gill histoarchitecture was similar to that observed at the lower dose (Fig.1). Hypertrophic mucous cells were detected containing glycoconjugate granules with 1,2-vic-glycol groups, neutral glycoconjugates and glycogen granules in the cytoplasm, as well as acid carboxylated and acid sulphated groups in addition to syalomucins. Type IV cells presented acid and neutral glycoconjugates.

In the acute exposition ( 24 hours), the $40 \mu \mathrm{l} / \mathrm{L}$ group lamellae showed no differences due to fusion by tissue hyperplasia. However, cellular infiltration due to gill he-

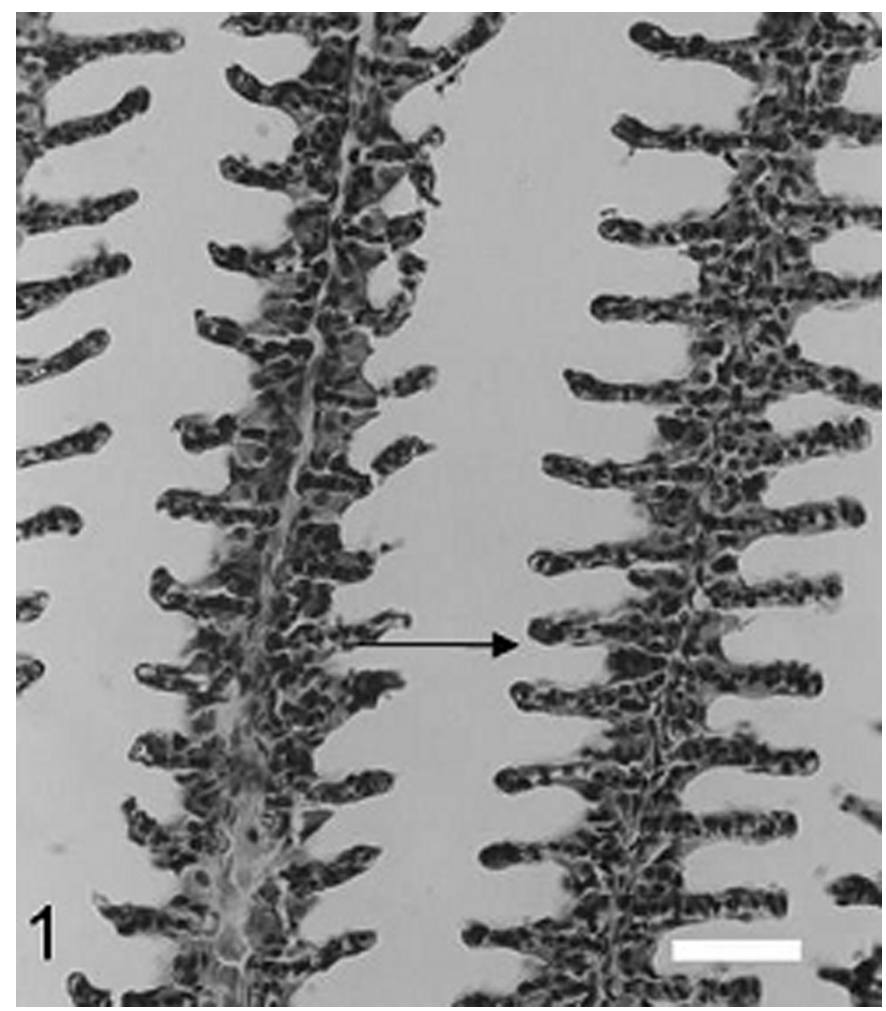

Fig.1. Gill morphology. Lamellae presenting loss of natural anatomic curve (arrow) in the $20 \mu \mathrm{l} / \mathrm{L}$ group. HE staining (Scale bar: $1 \mathrm{~cm}=95.2 \mu \mathrm{m})$.

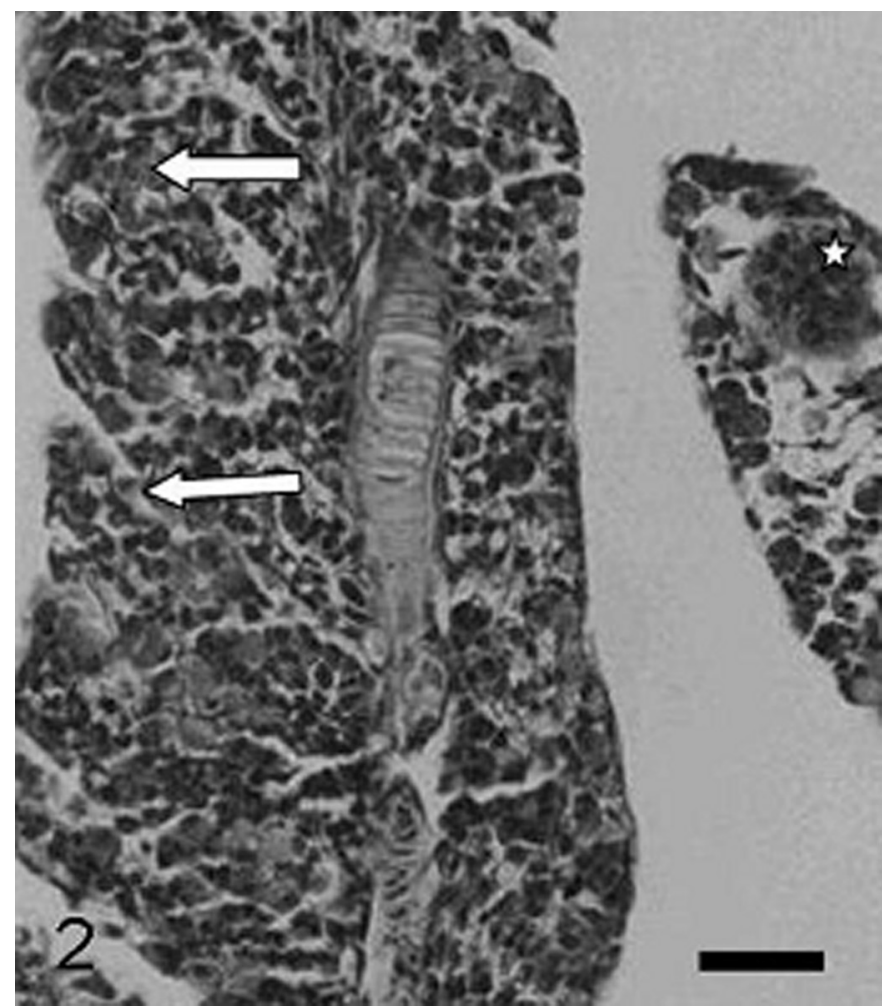

Fig.2. Lamellar fusion (arrow) and inflammation (star) in the $40 \mu \mathrm{l} / \mathrm{L}$ group. HE staining (Scale bar: $1 \mathrm{~cm}=111 \mu \mathrm{m}$ ).

morrhaging was observed, and picnotic nuclei showed highly condensed chromatin, suggesting tissue necrosis. Finally, pillar cell severance and inflammation were also observed (Fig.2). Classic histochemical analysis of fish exposed to $40 \mu \mathrm{l} / \mathrm{L}$ 2,4-D revealed hypertrophic mucous cells along gill filaments and rakes with granules rich in glycoconjugates with 1,2-vic-glycol groups, neutral glycoconjugates, a high quantity of acid carboxylated groups and the presence of syalomucins as well as acid carboxylated and neutral glycoconjugates.

The most common liver alterations observed were swollen nuclei and cytoplasmic vacuolization. In the control group, the hepatic epithelium contained cells organized in regular strings from the central vein, sinusoids with evident nuclear red cells, and hepatocytes with smooth basophilic cytoplasm. The epithelial cells contained decondensed nuclear chromatin and evident nucleoli; both were weakly acidic. PAS-positive hepatocytes presented negative reactions to PAS+salivary amylase and to PAS+acetylation. Reaction to PAS+reversible acetylation was not observed. In the $10 \mu \mathrm{l} / \mathrm{L}$ group, the epithelium contained cells that showed reduced cytoplasm in addition to vacuolization and rupture sites. These cells were also highly reactive to PAS and not reactive to PAS+salivary amylase and PAS+acetylation, indicating the presence of glycogen. These cells were also reactive for PAS+reversible acetylation, enabling the identification of glycogen as the PAS-reactive substance.

In the $20 \mu \mathrm{l} / \mathrm{L}$ group, cytoplasmic vacuolization and cytoplasmic damage were observed, and hepatocyte nuclei were visible. Only a few cells remained intact. Hepa- 


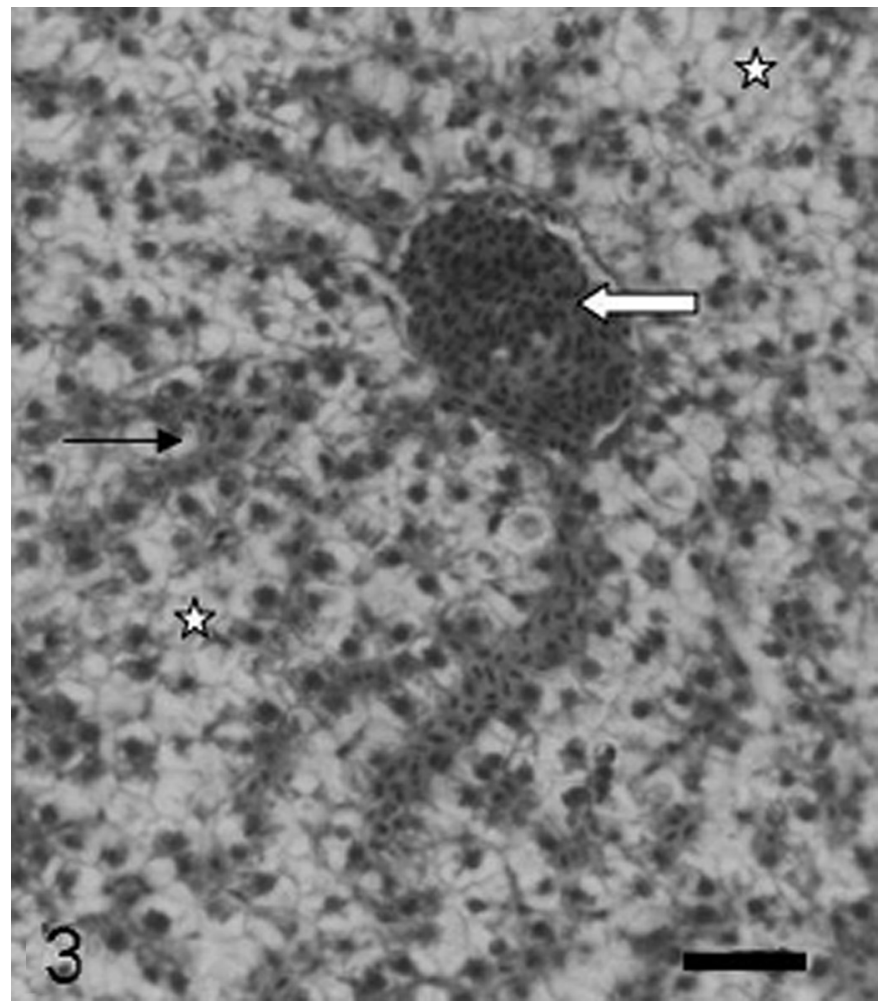

Fig.3. Histochemical reactions in the liver. Cytoplasmatic vacuolization (star), sinusoids (arrow) and blood vessel (white arrow) observed in the $20 \mu \mathrm{l} / \mathrm{L}$ group. HE staining (Scale bar: $1 \mathrm{~cm}=95.2 \mu \mathrm{m})$.

tocytes were highly reactive to PAS and PAS+reversible acetylation, but not reactive to PAS+salivary amylase or PAS+acetylation, indicating the presence of glycogen (Fig.3). Finally, the $40 \mu \mathrm{l} / \mathrm{L}$ group presented blood vessel alterations indicating vasodilatation, hepatocytes with swollen nuclei, Ito cells, and micronuclei (Fig.4). All experimental groups had PAS-reactive hepatocytes. Cells had low reactivity to PAS+reversible acetylation, indicating neutral glycoconjugates and the presence of glycogen. Cytoplasmic vacuolization and toluidine blue vesicle staining in $1 \mu \mathrm{m}$ sections suggested the presence of lipid vesicles in the cytoplasm. Water samples analyzed by Saneago did not show any physical, chemical, or bacteriological alterations (Datas: 0,03 mg/L - P; 0,02 mg/L - N-NO ; 0,0 mg/L - N-NO pH 6,7. / Total coliform - 3.000 NMP/100 ml; Termoresistent coliform - <200; $E$. coli - negative.

\section{DISCUSSION}

The estimated lethal concentration of 2,4-D herbicide for Poecilia vivipara is $34.64 \mu \mathrm{l} / \mathrm{L}$. The World Health Organization (WHO 1998) determined through pattern tests that the maximum amount of 2,4-D permitted in potable water is $30 \mu \mathrm{l} / \mathrm{L}$. Furthermore, the actions of $2,4-\mathrm{D}$ are not fully known, but they may affect human beings and create even larger environmental problems in the future. Most of the tests used to determine toxicological indices are typically performed in only a few animal species; often, the results cannot be extrapolated to other species. Thus, experimen-

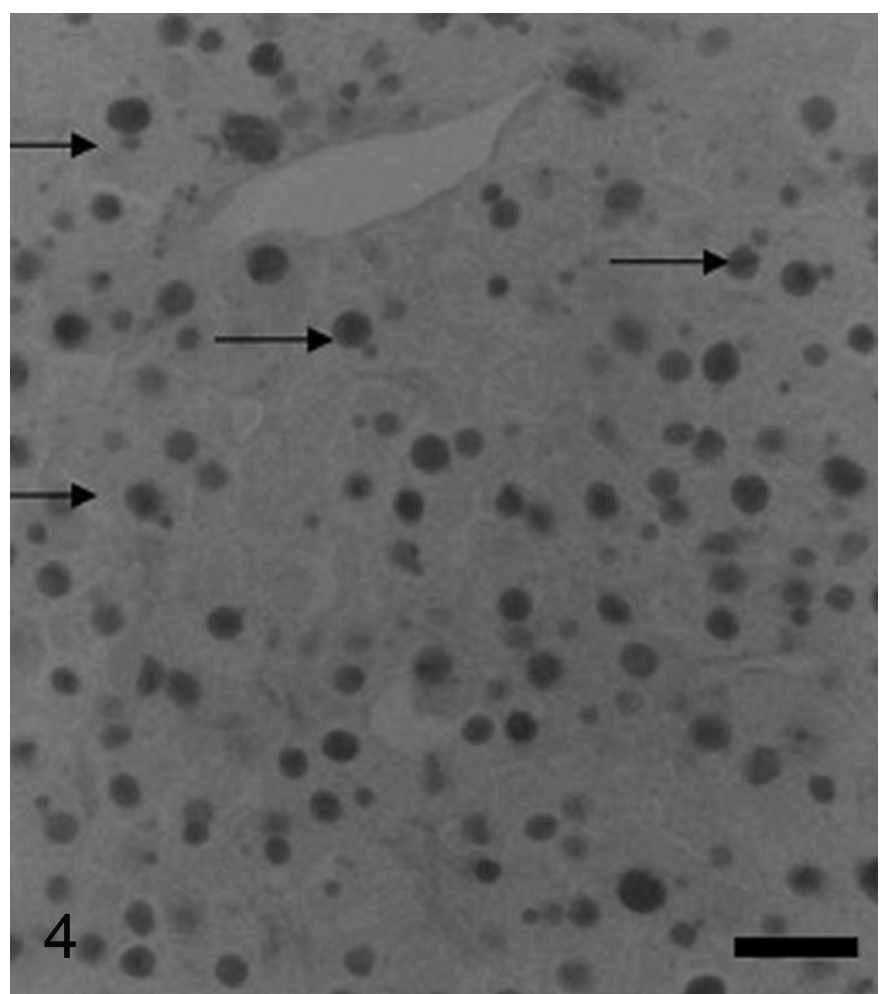

Fig.4. Presence of micronuclei (arrows) positively stained with Feulgen's reaction (Scale bar: $1 \mathrm{~cm}=111 \mu \mathrm{m}$ ).

tal tests that use non-typically analyzed species are important for further confirmation of toxicity. The label of the U46 ${ }^{\circledR}$ D-FLUID 2,4-D product indicates that it should be used for different types of crops at pre-established dosages per hectare. However, people who handle the product at farms do not usually follow the instructions on the label because many of them are illiterate or careless. This condition can result in considerable increases in the herbicide concentrations used, which may, in turn, greatly affect the environment. 2,4-D herbicide is inexpensive and is thus easily obtained and abused.

Impact of contaminants on tropical ecosystems has been the subject of few studies; thus, more tropical ecotoxicological studies must be performed on the effects of contaminants on native aquatic organisms (Winkaler et al. 2001). Effects of toxic substances on fish can manifested at many levels of biological organization, including physiological dysfunction, abnormalities in tissue and organ structure, and behavioral changes that can impede reproduction and growth (Adams et al. 1990). The aquatic neotropical biological model (Poecilia vivipara) used in the present study can be used to analyze the effects of 2,4-D herbicide on fish because this species showed a strong response in toxicological and behavioral essays as well as morphological analyses. The fish also presented altered cellular behavior when they were first placed in contaminated water. This work suggests a positive relationship between exposure to 2,4-D herbicide and histopathological alterations in the gills and liver. This and many previous studies indicate that these reactions are responses to 2,4-D herbicide toxi- 
city (Oruc et al. 2004). Histopathological anomalies in the gills due to contamination by pesticides and other toxic agents have been revealed by many investigators (Abdel-Moneim et al. 2012, Menezes-Faria et al. 2007, Simonato et al. 2008). Gills are the first route of entry for pesticides into fish, and, in response to environmental changes, they may present adaptive strategies to preserve physiological function (Menezes-Faria et al. 2007). The liver, which has a major detoxification function, can metabolize or accumulate contaminants in order to prevent toxic pollutants from reaching more vulnerable organs; however, in such situations, the liver itself will sustain morphological and physiological alterations (Au 2004). For these reasons, the gills and liver were chosen as target organs for the present study.

Histopathological analyses revealed stiffness of lamellae in groups receiving 10 and $20 \mu \mathrm{l} / \mathrm{L}$ of 2,4-D herbicide per liter of water. This suggests compensation for the decreased respiratory region via increased interlamellar space and gas exchange surface area. In the $40 \mu \mathrm{l} / \mathrm{L}$ group, hyperplasic alterations to the branchial epithelia suggest an attempt to increase mucus secretion and consequently protect the organ. Lamellar fusion is a similar defense mechanism that decreases the gas exchange surface vulnerable to the action of the herbicide. Similar data were described by Zodrow et al. (2004) in investigation using acute exposition. Such defense mechanisms presented as a response to pollutant agents are mostly irreversible toxic effects (Ortiz et al. 2003). Histopathological alterations can thus be used as efficient indicators of toxicity in fish. The high bioavailability of many chemical substances in water is an additional factor influencing their heightened toxicity in aquatic organisms. Analyses carried out by Wendelaar Bonga (1997 Apud Farah et al. 2004) showed that stressor agents could increase the permeability of epithelial surfaces, including gills to water and ions, thus resulting in hydromineral imbalance. According to Hinton and Laurén (1990), histopathological alterations were found by Eller (1971) in Oncorhynchus clarki exposed to Endrin, and by Virtanen (1986) in Poecilia reticulate exposed to DDT. Considering the polarity of 2,4-D herbicide, it is possible that this molecule could easily contact and interact with branchial epithelium cells. Once exposed to such stress-inducing agents, fish experience increased mucus production that can compromise gas exchange due to mucus plaque formation on the lamellar surface.

Mucins are glycoproteins that protect mucosa from environmental factors and are expressed in vertebrates and invertebrates. In fish, these proteins are involved in gill protection. Mucins with a high content of sialic acids, called syalomucins, are responsible for mucosal viscosity, as are mucins with neutral granules. The presence of granules with sulphated acid groups decreases mucus viscosity (Sayer \& Blackstock 1988). According to Allen (1981) and Verdugo (1990), mucosal viscosity increases when the ion concentration decreases. Classic histochemical analyses of all experimental groups in the present study revealed that mucosal cells of all fish contained neutral mucus groups as they were exposed to increasing concentrations of 2,4-D. The mucus became enriched in acidic groups; the resistan- ce to methylation indicated the presence of syalomucins. Mucosal viscosity is closely related to osmotic balance and gas exchange. When the mucosal viscosity is high, the permeability of the mucus is decreased, resulting in osmotic imbalance and inhibition of gas exchange.

Livers of fish exposed to 10 and $20 \mu \mathrm{l} / \mathrm{L}$ of 2,4-D herbicide presented hepatic tissue that was altered in the core, central region; vacuolated hepatocytes were observed with a spongy aspect, indicating hepatic spongiosis. In the peripheral region, hepatocytes looked similar to those of the control group. This effect was also observed by Hinton and Laurén (1990), indicating that hepatocytes located near biliary ducts are more often affected by toxic substances than those from other regions. According to Ortiz et al. (2003), after exposure to toxic substances, hepatocytes showed vacuoles that presented as clear vesicles occupying the entire cytoplasm, thus indicating the toxic potential of 2,4-D herbicide. The vacuolated aspect of hepatocytes found in fish exposed to 10 and $20 \mu \mathrm{l} / \mathrm{L}$ of 2,4-D implies that spongiosis can evolve tumor formation, which was confirmed by Hinton and Laurén (1990) and Santos et al. (2010). Initial process of necrosis in the group exposed to $40 \mu \mathrm{l} / \mathrm{L}$ of 2,4-D may be indicated by increase of collagen distribution and rise of Ito (stellate) cells; these are perisinusoidal cells that contain vacuoles of fat and indented nuclei and that are responsible for tumor defense. A similar analysis was performed by Jaeschke et al. (2002) and Krizhanovsky et al. (2008). Histopathological hepatic alterations such as hepatocyte vacuolization in the 10 and $20 \mu \mathrm{l} / \mathrm{L}$ groups and swollen nuclei in the $40 \mu \mathrm{l} / \mathrm{L}$ group suggest a physiological response to cellular stress upon exposure to a toxic agent. In accordance with the studies of Hinton \& Laurén (1990) and Menezes-Faria (2009) these alterations likely occurred because the liver is important for many nutritional functions such as lipid and carbohydrate storage. The liver is also the main site of drug metabolism and activation of potential carcinogenic substances that can cause neoplastic changes.

Micronuclei detected in the $40 \mu \mathrm{l} / \mathrm{L}$ group suggest tumor formation, thus identifying the genotoxic potential of 2,4-D herbicide. According to Grisolia (2002), fish micronuclei can be readily used for genotoxic assessment, as it is a simple short-term method applied to the biomonitoring of fresh water quality. Fish are efficient bioindicators because they have different functions in the ecosystem. They accumulate substances in their tissues, present responses to mutagenic substances in low concentrations, and show physiological responses similar to those of mammals (Minissi et al. 1996). Classic assessments of biological effects of chemical substances on aquatic organisms have been based on the results of toxicity tests and alterations in morphological and physiological patterns (Costa et al. 2010; Babinska 2010). Such standard protocols provided an efficient tool of moderate cost for monitoring of potential adverse effects of 2,4-D herbicide on Poecilia vivipara. The present study about the acute toxicity of 2,4-D herbicide represents an important tool for assessing possible risks to similar species in the aquatic environment and for determining ecotoxicological, morphological and biochemical standards in cases of contamination with toxic substances. 
Poecilia vivipara is a good biological model because it is a native species with moderate sensitivity, is easily adaptable to laboratory work and presents fast physiological responses to environmental alterations.

Acknowledgements.- This study was partially supported by Funape (Fundação de Apoio à Pesquisa da Universidade Federal de Goiás).

\section{REFERENCES}

Abdel-Moneim A.M., Al-Kahtani M.A. \& Elmenshawy O.M. 2012. Histopathological biomarkers in gills and liver of Oreochromis niloticus from polluted wetland environments, Saudi Arabia. Chemosph. 88:1028-1035.

Adams S.M., Shugart L.R., Southworth G.R. \& Hinton D.E. 1990. Application of bioindicators in assessing the health of fish populations experiencing contaminant stress, p.333-353. In: McCarthy J.F. \& Shugart L.R. (Eds), Biomarkers of Environmental Contamination. Lewis Publishers, Boca Raton, FL. (Apud Winkaler et al. 2001)

Allen A. 1981. Structure and Function of Gastrointestinal Mucus: physiology of the gastrointestinal tract. Raven Press, New York. Cap.21. (Apud Hinton \& Laurén 1990)

Au D.W.T. 2004. The application of histo-cytopathological biomarkers in marine pollution monitoring: a review. Mar. Pol. Bul. 48:817-834.

Babinska I. 2010. Structural lesions of tissues and cells influenced by environmental pollution. Contemp. Probl. Manag. Environ. Protec. 5:121131.

Costa P.M., Chicano-Gálvez E., Barea J.L., Del Valls T.A. \& Costa M.H. 2010. Alterations to proteome and tissue recovery responses in fish liver caused by a short-term combination treatment with cadmium and benzo[a]pyrene. Environ. Pol. 158:3338-3346.

Eller L.L. 1971. Histopathologic lesions in cutthroat trout (Salmo clarkii) exposed chronically to the insecticide endrin. Am. J. Pathol. 64:321-336. (Apud Hinton \& Laurén 1990)

Farah M.A., Ateeq B., Ali M.N., Sabir R. \& Ahmad W. 2004. Studies on lethal concentrations and toxicity stress of some xenobiotics on aquatic organisms. Chemosph. 55:257-265.

Fent K. 2003. Ecotoxicological problems associated with contaminated sites. Toxicol. Lett. 140(141):353-365. (Review)

Fent K. 2004. Ecotoxicological effects at contaminated sites. Toxicol. 205: 223-240.

Grisolia C.K. 2002. A comparation between mouse and fish micronucleus test using cyclophosphamide, mitomycin $\mathrm{C}$ and various pesticides. Mut. Res. 517:145-150.

Henares M.N.P., Cruz C., Gomes G.R., Pitelli R.A. \& Machado M.R.F. 2008. Toxicidade aguda e efeitos histopatológicos do diquate na brânquia e no fígado da tilápia nilótica (Oreochromis niloticus). Acta Scient. Biol. Sci. 30:78-82.

Hinton D.E. \& Laurén D.J. 1990. Integrative histopathological approaches to detecting effects of environmental stressors on fish, p.51-66. In: Adams S.M. (Ed.), Biological Indicators of Stress in fish. Bethesda: $8^{\text {th }}$ American Fishery Society Symposium, Bethesda.

Jaeschke H., Gores G.J., Cederbaum A.I., Hinson J.A., Pessayre D. \& Lemasters J.J. 2002. Mechanisms hepatotoxicity. Toxicol. Sci. 65:166-176.

Krizhanovsky V., Yon M., Dickins R.A., Hearn S., Simon J., Miething C., Yee H., Zender L. \& Lowe S.W. 2008. Senescence of activated stellate cells limits liver fibrosis. Cell 134(4):657-667.

Menezes-Faria J.C.N., Vigário A.F., Rocha T.L. \& Sabóia-Morais S.M.T. 2007. Effects induced by agrochemical on epithelial morphology on gills of guppy. Comp. Physiol. Biochem. A 148: S79. (Abstract)
Menezes-Faria J.C.N. 2009. Avaliação histopatológica, histoquímica e morfométrica dos efeitos da toxicidade aguda do herbicida Roundup ${ }^{\circledR}$ nas brânquias e no fígado do peixe Poecilia vivípara. Dissertação de Mestrado em Biologia, Instituto de Ciências Biológicas, Universidade Federal de Goiás, Goiânia, G0. 106p.

Minissi S., Ciccotti E. \& Rizzoni M. 1996. Micronucleus test in erythrocytes of Barbus plebejus (Teleostei, Pisces) from two natural environments: a bioassay for the in situ detection of mutagens in freshwater. Mut. Res. 367:245-251.

Ortiz Juan B., Gonzalez de Canales M.L. \& Sarasquete C. 2003. Histopathological changes induced by lindane $(\gamma-\mathrm{HCH})$ in various organs of fish. Sci. Mar. 67:53-61.

Oruc E.O., Sevgiler Y. \& Uner N. 2004. Tissue-specific oxidative stress responses in fish exposed to 2,4-D and azinphosmethyl. Comp. Biochem. Physiol. C 137:43-51.

Ozmen M., Ayas Z., Güngördü A., Ekmekci G.F. \& Yerli S. 2008. Ecotoxicological assessment of water pollution in Sariyar Dam Lake, Turkey. Ecotoxicol. Environ. Saf. 70:163-173.

Rao J.V. 2006. Toxic effects of novel organophosphorus insecticide (RPR-V) on certain biochemical parameters of euryhaline fish Oreochromis mossambicus. Pest. Biochem. Physiol. 86:78-84.

Rodrigues B.M. \& Almeida F.S. 1998. Guia de Herbicidas. 4를. ed. Editora dos Autores, Londrina. 648p.

Sabóia-Morais S.M.T., Hernandez-Blazquez F.J., Mota D.L. \& Bittencourt A.M. 1996. Mucous cells types in the branchial epithelium of the euryhaline fish Poecilia vivipara. J. Fish Biol. 49:45-548.

Santos A.P., Menezes-Faria J.C.N., Rocha T.L. \& Sabóia-Morais S.M.T. 2010. Estudo morfológico e histoquímico da hepatoxicidade do herbicida Roundup no fígado do Guaru (Poecilia vivipara). Anais 62ª Reunião Anual da SBPC, Natal, RN, p.40. (Resumo)

Sarikaya R. \& Yilmaz M. 2003. Investigation of acute toxicity and the effect of 2,4-D (2,4-dichlorophenoxyacetic acid) herbicide on the behavior of the common carp (Cyprinus carpio L., 1758; Pisces, Cyprinidae). Chemosph. 52:195-201.

Sayer M.D.J. \& Blackstock N. 1988. The relationship between nitrogen output and changes in mucous cell function in the amphibious teleost Blennius pholis L. during aerial exposure. J. Fish Biol. 32:765-776.

Simonato J.D., Guedes C.L.B. \& Martinez C.B.R. 2008. Biochemical, physiological, and histological changes in the neotropical fish Prochilodus lineatus exposed to diesel oil. Ecotoxicol. Environ. Saf. 69:112-120.

Spadotto C.A., Gomes M.A.F. \& Rodrigues G.S. 1998. Uso de agrotóxicos nas diferentes regiões brasileiras: subsídio para a geomedicina: pesticidas. Revta Ecotoxicol. Meio Amb. 8:111-126.

Verdugo P. 1990. Goblet cells secretion and mucogenesis. Ann. Rev. Physiol. 52:157-176.

Virtanen M.T. 1986. Histopathological and ultraestructural changes in the gills of Poecilia reticulatus produced by an organochlorine pesticide. J. Env. Pathol., Toxicol. Oncol. 7:73-85. (Apud Hinton \& Laurén 1990)

Wendelaar Bonga S.E. 1997. The stress response in fish. Physiol. Rev. 77: 591-625. (Apud Farah et al. 2001)

Winkaler E., Silva A.G., Galindo H.C. \& Martinez C.B.R. 2001. Biomarcadores histológicos e fisiológicos para o monitoramento da saúde dos peixes de ribeirões de Londrina, Estado do Paraná. Acta Scient. 23:507-514.

WHO 1998. Guidelines for drinking-water quality: hHealth criteria and other supporting information. $2^{\text {nd }}$ ed. World Health Organization, Genève.

Zodrow J.M., Stegeman J.J. \& Tanguay R.L. 2004. Histological analyses of acute toxicity of 2,3,7,8-tetrachlorodibenzo-p-dioxin (TCDD) in zebrafish. Aq. Toxicol. 66:25-38. 